\title{
PERUBAHAN WATAK HIDROLOGI SUNGAI-SUNGAI BAGIAN HULU DI JAWA
}

\author{
Sutopo Purwo Nugroho \\ Pusat Teknologi Sumberdaya Lahan, Wilayah dan Mitigasi Bencana, BPPTeknologi \\ J. M.H. Thamrin No. 8 Gd. II Lt. 18 Jakarta 10340
}

\begin{abstract}
The hydrological character of the rivers in Java has changed. The trend flow of upstream rivers in Java declined. Significance level of the trend decline in the upstream was large enough. This indicates that the basic flow (base flow) from these rivers has been reduced. The cause of the trend decline in river flow is strongly influenced by a combination of the effects of global climate change and the influence of anthropogenic. The influence of climate change is marked by decreasing annual rainfall. While anthropogenic influences include changes in land use, reduced water catchment area, increasing population pressures and settlements. To identify which factors are most influential between the two factors are very difficult to do because of limited data on land use change.
\end{abstract}

Keywords: discharge, trend, climate change, landuse, anthropogenic

\section{PENDAHULUAN}

Pengaruh perubahan iklim global telah menyebabkan pola curah hujan berubah. Bukan hanya tebal hujan yang berubah, namun intensitas, durasi dan sebaran curah hujan telah berubah. Dampak perubahan ini adalah berubahnya pola dan watak hidrologi sungai. Sebagian besar sumber debit sungai berasal dari curah hujan. Secara statistik jumlah hujan pada musim hujan (Oktober hingga Maret untuk wilayah Jawa) adalah 80 persen dari jumlah hujan tahunan. Perubahan pola musim terjadi dengan pertambahan lama musim kering dan peningkatan rasio jumlah hujan di musim hujan terhadap musim kering yang meningkat di atas 80 persen. Hal ini semakin diperparah dengan terjadi penurunan akumulasi total hujan tahunan secara persisten hampir di seluruh wilayah Indonesia dalam lima dekade terakhir sehingga potensi air tercurah berkurang ${ }^{3)}$.

Terlebih lagi sungai-sungai di Jawa yang sudah mengalami degradasi lingkungan. Tekanan penduduk terhadap lahan yang telah melampaui daya dukungnya menyebabkan timbul berbagai masalah yang berkaitan dengan air, yaitu banjir, kekeringan, pencemaran air, erosi, sedimentasi, eutrofikasi dan sebagainya. Namun demikian perubahan hidrologi, khususnya perubahan dari trend debit sungai-sungai di Indonesia belum banyak dikaji lebih mendalam. Watak hidrologi sebagian sungai-sungai di Indonesia sudah diteliti oleh beberapa ahli, diantara mengenai perubahan hidrograf banjir. Selain itu perubahan magnitude rata-rata per tahun debit sungai, pola musim dari watak hidrologi sungai juga berubah. Pada musim hujan terjadi kecenderungan kenaikan debit sungai yang dipengaruhi dari adanya perubahan watak hujan, di mana hujan dengan intensitas tinggi dan jeluk hujan yang besar serta durasi pendek lebih sering terjadi pada musim hujan dan sebaliknya hujan semakin berkurang selama musim kemarau ${ }^{3), 10)}$.

Menurunnya kecenderungan debit
sungai-sungai tentunya akan sangat
berpengaruh terhadap penyediaan air untuk kebutuhan penduduk dan lingkungan. Kecenderungan penurunan kondisi sumberdaya air di Pulau Jawa baik secara kualitas maupun kuantitas mengisyaratkan perlunya perhatian lebih besar diberikan untuk meningkatkan pengelolaannya. Di Jawa dan Bali ratio antara penggunaan dan dependable flow telah semakin meningkat. Pada tahun 1995 indeks penggunaan air (IPA) di Jawa adalah sekitar $51 \%$.

Tingkat IPA yang dianggap praktikal di beberapa negara adalah antara 30\% - 60\%. Bahkan di Wilayah Sungai Ciliwung-Cisadane (yang melayani Jabotabek), IPA-nya sudah mencapai $100 \%$. Ini artinya, antara dependable flow dan jumlah permintaan sudah hampir atau telah berimbang. Kenyataan kekeringan yang terjadi di beberapa tempat di Pulau Jawa sekarang cenderung tidak mampu lagi memenuhi kebutuhan air sendiri. Kondisi di daerah lain di Indonesia juga memperlihatkan kecenderungan ke arah penurunan kondisi sumberdaya air yang pada akhirnya, jika tidak ditangani dengan cara yang tepat, akan menimbulkan permasalahan ketersediaan air untuk memenuhi kebutuhan 11), 12), 13), 14). 


\section{METODE PENELITIAN}

\subsection{Daerah Penelitian}

Penelitian dilaksanakan di 8 sungai utama di Jawa, yaitu Ciujung, Cisadane, Citarum, Cimanuk, Citanduy, Sungai Serayu, Bengawan Solo, dan sungai Brantas. Sungai-sungai tersebut tergolong mempunyai luas DAS yang cukup besar. Luas daerah penelitian secara keseluruhan sekitar $36 \%$ dari luas daratan Pulau
Jawa. Sungai-sungai tersebut mencakup sungai strategis di Jawa dan di dalam kawasan DAS tersebut telah berkembang pusat-pusat pertumbuhan ekonomi dengan jumlah penduduk yang lebih besar dibandingkan dengan dengan DAS lainnya. Adanya perbedaan intensitas pemanfataan lahan, dimana kawasan di Utara Jawa mempunyai kepadatan penduduk dan industri yang lebih banyak jika dibandingkan dengan kawasan di selatan.

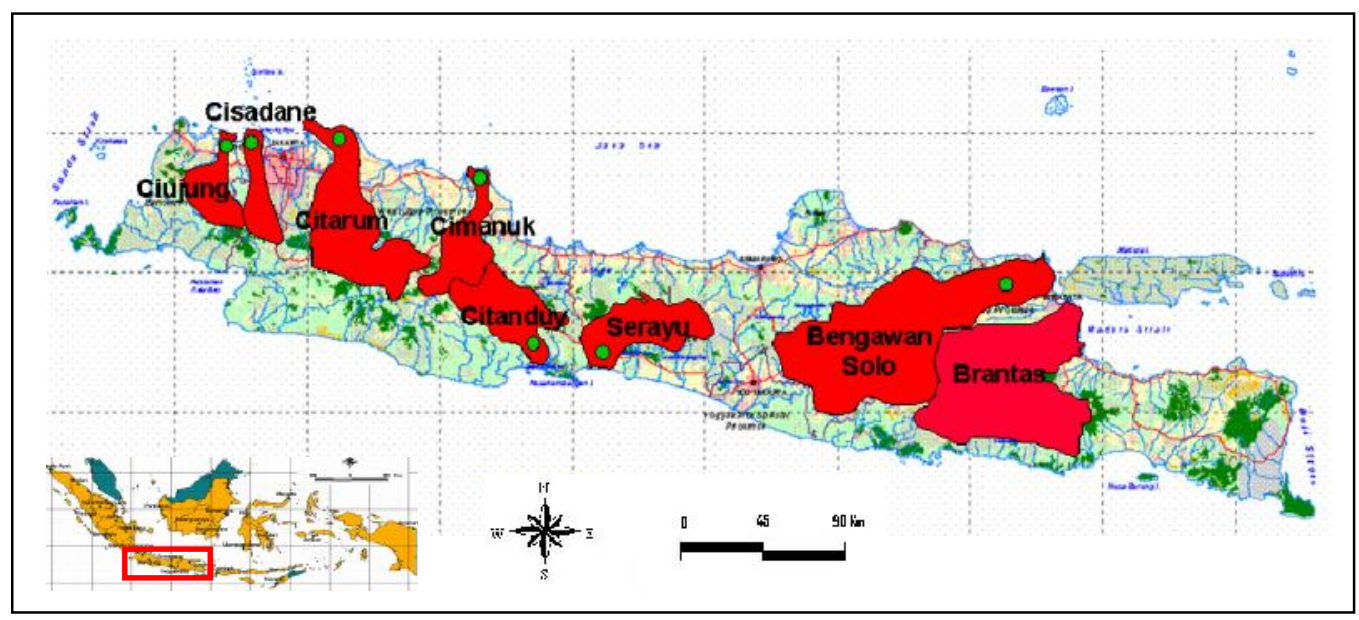

Gambar 1. Lokasi Penelitian

\subsection{Data Penelitian}

Di Pulau Jawa terdapat sekitar 459 pos duga air atau stasiun debit sungai yang tersebar di 111 DAS dengan lama pencatatan debit yang bervariasi. Dari 459 stasiun debit di Pulau Jawa tersebut, sebanyak 283 stasiun atau $61,7 \%$ tersebar di daerah penelitian, yaitu di DAS Ciujung (8 stasiun), DAS Cisadane (13 stasiun), DAS Citarum (74 stasiun), DAS Cimanuk (38 stasiun), DAS Citanduy (32 stasiun), DAS Serayu (35 stasiun), DAS Bengawan Solo (42 stasiun), dan DAS Brantas (41 stasiun).
Untuk analisis kecenderungan (trend) debit maka dilakukan pemilihan stasiun yang dapat mewakili bagian hulu DAS. Berdasarkan pertimbangan hal tersebut, maka di bagian hulu DAS diwakili oleh stasiun Ciberang, Legok Muncang, Cikapundung, Bojongloa, Cilisung, Banjarnegara, Padas, Nambangan dan Gadang (Tabel 1). Pada hulu DAS Bengawan Solo diwakili oleh dua stasiun dengan pertimbangan adanya dua sub DAS yang besar yaitu Bengawan Solo hulu dan Bengawan Madiun. Durasi pengamatan debit yang digunakan berkisar antara $16-33$ tahun.

Tabel 1. Stasiun debit yang digunakan untuk analisis kecenderungan debit di hulu DAS

\begin{tabular}{|c|l|r|l|c|c|c|}
\hline No & \multicolumn{1}{|c|}{ DAS } & $\begin{array}{c}\text { Luas DAS } \\
\left(\mathbf{k m}^{2}\right)\end{array}$ & \multicolumn{1}{|c|}{ Stasiun } & $\begin{array}{c}\text { Luas subDAS dari } \\
\text { Stasiun }\left(\mathbf{k m}^{2}\right)\end{array}$ & $\begin{array}{c}\text { Periode } \\
\text { Pengamatan }\end{array}$ & $\begin{array}{c}\text { Durasi } \\
\text { (tahun) }\end{array}$ \\
\hline 1 & Ciujung & 1.935 & Ciberang & 301 & $1986-2001$ & 16 \\
\hline 2 & Cisadane & 1.667 & Legok Muncang & 196 & $1976-2001$ & 26 \\
\hline 3 & Citarum & 6.080 & Cikapundung & 76 & $1969-2001$ & 33 \\
\hline 4 & Cimanuk & 3.600 & Bojongloa & 286 & $1974-2001$ & 28 \\
\hline 5 & Citanduy & 3.599 & Cilisung & 190 & $1973-2001$ & 29 \\
\hline 6 & Serayu & 3.383 & Banjarnegara & 270 & $1977-2001$ & 25 \\
\hline 7 & $\begin{array}{l}\text { Bengawan } \\
\text { Solo }\end{array}$ & 16.100 & Padas & 35 & $1974-2003$ & 30 \\
\cline { 5 - 7 } & & Nambangan & 2.126 & $1971-2001$ & 31 \\
\hline 8 & Brantas & 12.192 & Gadang & 808 & $1974-2005$ & 32 \\
\hline
\end{tabular}




\subsection{Analisis Data}

Berdasarkan data debit historis dari masing-masing stasiun hidrologi yang dianggap dapat mewakili dari hulu dilakukan analisis dengan menggunakan statistik Mann Kendall. Metode Mann Kendall merupakan salah satu metode statistik non parametric yang sering digunakan untuk mendeteksi trend ${ }^{19)}$.

Uji Mann-Kendall secara luas telah diterapkan untuk mendeteksi trend dalam waktu seri dari ilmu-ilmu lingkungan, termasuk musiman 6), pemantauan lokasi-lokasi ganda ${ }^{8)}$ and representasi fluktuasi alam ${ }^{9}$. Alasan populernya metode Mann Kendall adalah metode ini cukup sederhana, mampu mengatasi nilai-nilai yang hilang dan nilai-nilai di bawah batas yang diperoleh.

Tingkat signifikasi dari kecenderungan penurunan debit tersebut diindikasikan dari nilai $Z$ dan nilai $\alpha$, dimana semakin besar nilai $Z$ negatif maka semakin kuat bukti adanya penurunan. Sebaliknya jika nilai Z positif maka menunjukkan adanya kenaikan debit. Dalam metode Mann-Kendall tersebut penentuan nilai signifikasi (Z) menggunakan empat nilai alpha $(\alpha)$ yang berbeda yaitu sebagai berikut :

a) Untuk $\alpha=0,1$ atau dengan tingkat kepercayaan $90 \%$ jika nilai $\operatorname{Abs}(Z)>1,645$ maka nilai signifikan ditandai dengan tanda "+"

b) Untuk $\alpha=0,05$ atau dengan tingkat kepercayaan 95\%, jika nilai $\operatorname{Abs}(Z)>1,96$ maka nilai signifikan ditandai dengan tanda "“*”,

c) Untuk $\alpha=0,01$ atau dengan tingkat kepercayaan 99,99\%, jika nilai $\operatorname{Abs}(Z)>$ 2,576 maka nilai signifikan ditandai dengan tanda "**"

d) Untuk nilai $\alpha=0,001$ atau dengan tingkat kepercayaan 99,999\%, jika nilai $\operatorname{Abs(Z)~>~}$
3,292 maka nilai signifikan ditandai dengan tanda "***".

\section{HASIL DAN PEMBAHASAN}

\subsection{Kecenderungan Debit Tahunan}

Dalam analisis kecenderungan dengan metode Mann-Kendall ini, untuk hulu DAS Bengawan Solo dilakukan di dua stasiun untuk mewakili dua sub DAS yang luas yaitu stasiun Padas untuk sub DAS hulu Bengawan Solo dan stasiun Nambangan untuk DAS Bengawan Madiun. Sedangkan untuk stasiun Gadang yang mewakili hulu DAS Brantas, perhitungan dilakukan dalam dua periode yang berbeda yaitu periode tahun 1974-1987 dan 1991-2003. Hal ini disebabkan pada tahun 1990 peralatan pengukur debit di stasiun Gadang diganti dengan peralatan otomatis dan hasil pencatatan debit yang dihasilkan lebih besar jika dibandingkan dengan periode sebelumnya. Pencatatan data tersebut berlangsung hingga tahun 2003 sehingga dalam perhitungan kecenderungan periode waktu tersebut dipisahkan.

Berdasarkan hasil perhitungan kecenderungan debit sungai dengan menggunakan metode Mann-Kendall dari data debit sungai rata-rata tahunan untuk daerah hulu, menunjukkan bahwa semua sungai di daerah penelitian mempunyai kecenderungan menurun dengan nilai signifikasi yang cukup tinggi. Tiga stasiun di bagian hulu yang memiliki nilai signifkasi yang tinggi dengan $\alpha=0,001$ yaitu di stasiun Bojongloa-Cimanuk, Padas-Bengawan Solo, dan Gadang-Brantas (1974-1987). Nilai Z ketiga stasiun tersebut adalah $-3,42 ;-4,17$ dan 3,37. Berturut-turut di stasiun Ciberang-Ciujung, Legok Muncang-Cisadane, CikapundungCitarum, Cilisung-Citanduy, dan Gadang (19912003) - Brantas mempunyai nilai $Z>1,96$ atau $\alpha$ $=0,05($ Tabel 2)

Tabel 2. Pola kecenderungan debit sungai tahunan di bagian hulu DAS

\begin{tabular}{|c|c|c|c|c|c|c|}
\hline \multirow[b]{2}{*}{ No } & \multirow[b]{2}{*}{ Stasiun - Sungai } & \multicolumn{2}{|c|}{ Mann-Kendall } & \multicolumn{2}{|c|}{ Regresi Linier } & \multirow{2}{*}{$\begin{array}{c}\text { Kekritisan } \\
\text { (Q/b) }\end{array}$} \\
\hline & & Z & $\begin{array}{c}\text { Nilai } \\
\text { Signifikansi }\end{array}$ & $\mathrm{Q}$ (m³/detik) & $\begin{array}{c}\text { b } \\
\text { (m³/detik) }\end{array}$ & \\
\hline 1 & Ciberang - Ciujung & $-2,12$ & * & $-11,72$ & 417,17 & $-0,028$ \\
\hline 2 & Legok Muncang - Cisadane & $-2,23$ & * & $-1,51$ & 185,75 & $-0,008$ \\
\hline 3 & Cikapundung - Citarum & $-2,19$ & * & $-0,47$ & 50,22 & $-0,001$ \\
\hline 4 & Bojongloa - Cimanuk & $-3,42$ & $\star \star \star$ & $-3,22$ & 165,62 & $-0,019$ \\
\hline 5 & Cilisung - Citanduy & $-2,01$ & * & $-3,04$ & 144,51 & $-0,021$ \\
\hline 6 & Banjarnegara - Serayu & $-2,76$ & ** & $-7,68$ & 748,03 & $-0,010$ \\
\hline 7 & Padas - B. Solo & $-4,17$ & $\star \star \star$ & $-0,58$ & 20,10 & $-0,003$ \\
\hline 8 & Nambangan - B. Solo & $-2,03$ & * & $-10,56$ & 511,24 & $-0,021$ \\
\hline 9 & Gadang (1974-1987) - Brantas & $-3,37$ & 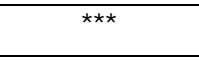 & $-16,89$ & 330,88 & $-0,051$ \\
\hline 10 & Gadang (1991-2003) & $-2,26$ & * & $-8,13$ & 554,31 & $-0,015$ \\
\hline
\end{tabular}


Besarnya penurunan debit dari kecenderungan yang ditunjukkan oleh nilai $Q$ dalam metode Mann-Kendall pada masingmasing sungai bervariasi $-0,47 \mathrm{~m}^{3} /$ detik hingga $41,36 \mathrm{~m}^{3} /$ detik, yaitu terendah terjadi di stasiun Cikapundung - Citarum -0,47 $\mathrm{m}^{3} /$ detik dan terbesar di Stasiun Gadang (1974-1987) Brantas sebesar $-16,89 \mathrm{~m}^{3} /$ detik. Berturut-turut penurunan debit terjadi di stasiun CiberangCiujung - $11,72 \mathrm{~m}^{3} /$ detik, Legok MuncangCisadane -1,51 $\mathrm{m}^{3} /$ detik, Bojongloa-Cimanuk $3,22 \mathrm{~m} 3 /$ detik, Cilisung-Citanduy $-3,04 \mathrm{~m} 3 /$ detik, Banjarnegara-Serayu $-7,68 \quad \mathrm{~m}^{3}$ detik, Nambangan-Bengawan Solo $-10,56 \mathrm{~m}^{3} / \mathrm{detik}$, Padas-Bengawan Solo $-0,58 \mathrm{~m}^{3} /$ detik dan Gadang (1991-2003)-Brantas $\quad-8,13 \quad \mathrm{~m}^{3} /$ detik (Tabel 2).

Sedangkan nilai $b$ yang menyatakan intersep dalam regresi linier atau kapasitas debit awal berkisar antara $-20,1 \mathrm{~m}^{3} /$ detik di stasiun Padas-Bengawan Solo hingga 748,03 m³/detik di stasiun Banjarnegara-Serayu. Tingkat kekritisan yang dinyatakan dalam rasio antara nilai $Q$ dan $b$ berkisar antara $-0,001$ hingga $-0,051$. Semakin kecil nilai rasionya maka semakin kecil tingkat kekritisan yang ada karena laju penurunan terhadap kapasitas awal semakin kecil yang berarti trend penurunan debit tidak terlalu besar dibandingkan dengan kapasitas awal debit. Dari indikator ini, stasiun Gadang memiliki tingkat kekritisan tertinggi, sedangkan terendah terjadi di stasiun Cikapundung. Pola kecenderungan debit di bagian hulu dari 8 sungai di daerah penelitian disajikan pada Gambar 2 pada lampiran.

Terjadinya pola kecenderungan penurunan debit di bagian hulu dari sungaisungai di daerah penelitian mengindikasikan bahwa tingkat kerusakan lahan sudah sangat mengkhawatirkan. Debit sungai semakin mengecil yang berlangsung sepanjang tahun. Terlebih pada musim kemarau di saat curah hujan jarang dan aliran air tanah (base flow) sudah sangat kecil. Implikasi dari penurunan kecenderungan debit sungai tersebut adalah berkurangnya pasokan air sungai sehingga timbul kekeringan, meningkatnya pencemaran air sungai, dan kerusakan lingkungan. Sebab debit sungai sangat bermanfaat bagi penyediaan air irigasi, kebutuhan air domestik, sanitasi lingkungan, dan penyokong kehidupan biota perairan dan serta lingkungan. Hal inilah yang akan secara langsung terpengaruh oleh makin berkurang debit sungai.

Berdasarkan pada hasil analisis kecenderungan debit hulu sungai dari 8 sungai utama di Jawa, terlihat semua sungai di daerah penelitian mempunyai kecenderungan turun. Artinya debit sungai semakin mengecil dan kecenderunganya semakin meningkat. Beberapa faktor yang menyebabkan semakin menurunnya kecenderungan debit di bagian hulu antara lain: a) banyaknya penggunaan air di untuk keperluan irigasi pertanian 12), b) berkurangnya curah hujan, sebagai misal di DAS Brantas selama periode 1955-2002 3), 14), c) pengaruh dari adanya pengaturan tata air dari waduk-waduk besar di bagian hulu 7), 1), 4), 5), d) menurunnya aliran dasar (base flow) di bagian hulu 16).

Di bagian hulu, Sungai Brantas mengalami penurunan debit sebesar $-16,89$ $\mathrm{m}^{3} /$ detik (1974-2005) dan Sungai Serayu -7,68 $\mathrm{m}^{3} /$ detik (1977-2001). Sungai-sungai lainnya seperti Sungai Ciujung, Cisadane, Citarum, Cimanuk, dan Citanduy terjadi penurunan yang lebih kecil. Perubahan debit sungai secara musiman yang berlangsung sepanjang musim terjadi di sebagian besar dari sungai-sungai di daerah penelitian. Terlebih lagi di DAS Bengawan Solo hulu yaitu di stasiun Padas, trend penurunan debit secara signifikan terlihat dari besarnya nilai $Z$ yang cukup besar sepanjang musim. Artinya trend penurunan debit tersebut terjadi dalam periode 30 tahun secara signifikan. Perubahan yang nyata dari penurunan debit tersebut disebabkan luas DAS dari stasiun Padas yang relatif kecil yaitu $35 \mathrm{~km}^{2}$ sehingga pengaruh hujan dan perubahan penggunaan lahan langsung terespon oleh debit sungai.

Dampak pengaruh perubahan iklim global terhadap pola curah hujan nampak nyata telah terjadi di Jawa. Secara umum trend linear panjang musim di wilayah-wilayah pegunungan memendek musim hujannya (musim kemaraunya memanjang) dengan tingkat laju perubahan sedang, sedangkan wilayah dataran rendah umumnya trend linear panjang musim hujannya memanjang (musim kemarau memendek) dengan tingkat laju perubahan rendah. Trend linear jumlah curah hujan musim kemarau di hampir seluruh daerah musim di Jawa arah perubahannya berkurang, demikian juga trend linear jumlah curah hujan musim hujan di sebagian besar daerah musim di Jawa juga berkurang. Hanya sebagian kecil daerah musim yang trend linearnya bertambah.

Di sebagian besar wilayah Indonesia rata-rata curah hujan tahunan periode 2010-2020 diproyeksikan akan berkurang dibanding ratarata curah hujan tahun periode 1978-2007. Ratarata curah hujan periode tahun 2016-2020 diproyeksikan lebih kering dibanding periode tahun 2010-2015.

\subsection{Kecenderungan Debit Bulanan}

Dengan menggunakan metode MannKendall untuk melihat perubahan pola kecenderungan debit secara bulanan dari masing-masing stasiun dapat diamati dari nilai $Z$ bulanan. Pada Tabel 3 disajikan nilai $Z$ pada 
masing-masing stasiun per bulan. Berdasarkan nilai $Z$ dengan tingkat signifikasi yang cukup tinggi yang digunakan untuk analisis yaitu pada $\alpha=0,1$ hingga $\alpha=0,001$, maka terlihat bahwa semua stasiun pengamatan debit memiliki penurunan kecenderungan pada bulan-bulan tertentu.

Secara umum dapat dikatakan bahwa kecenderungan bulanan debit sungai di bagian hulu mempunyai kecenderungan turun dengan tingkat signifikasi yang bervariasi. Kecenderungan penurunan debit secara signifikan terjadi selama musim penghujan hingga musim transisi dari hujan ke kemarau yaitu dari Desember hingga Mei. Sedangkan pada musim kemarau yaitu dari Juni hingga November juga terjadi penurunan debit namun tingkat signifikasinya cukup kecil, kecuali di Cikapundung, Bojongloa dan Gadang (Tabel 3).

Pada stasiun Padas hulu Bengawan Solo, tingkat signifikasi kecenderungan penurunan debit sangat tinggi di sepanjang tahun. Terdeteksinya nilai $Z$ yang demikian besar disebabkan oleh ukuran DAS dari stasiun Padas yang lebih kecil dibandingkan dengan stasiunstasiun lainnya. Luas DAS dari stasiun Padas hanya $35 \mathrm{~km}^{2}$ sehingga respon perubahan aliran dari faktor-faktor yang mempengaruhinya, seperti curah hujan dan penggunaan lahan secara langsung memberikan perubahan pada debit sungai. Stasiun Padas merupakan salah satu stasiun pengamatan mikro DAS yang dikelola oleh Balitbang Departemen Kehutanan sehingga data debit yang terekam cukup panjang dari tahun 1974 hingga sekarang.

\section{KESIMPULAN}

Trend debit sungai-sungai di bagian hulu di Jawa mengalami penurunan secara signifikan. Tingkat signifikansi penurunan trend di bagian hulu cukup besar. Hal ini mengindikasikan bahwa aliran dasar dari sungai-sungai tersebut sudah berkurang. Trend penurunan debit tersebut merupakan kombinasi dari pengaruh perubahan iklim global dan pengaruh dari antropogenik. Sangat sulit memisahkan kedua faktor tersebut karena terbatasnya data perubahan penggunaan lahan.

\section{DAFTAR PUSTAKA}

1. Admiraal, W., Breugem, P., Jacobs, D., Stevenick, D.R., (1990) Fixation of Dissolved Silicate and Sedimentation of Biogenic Silicate in the Lower River During Diatom Blooms. Biogeochemistry 9. 175-185.

2. Aldrian, E., Nugroho, S.P., Adi, S., Prihartanto, Sudiana, N. (2006) The Final Project Report: The Brantas Catchment Water and Carbon Cycle. The Southeast Asia Regional Center for START (SARCS) BPPT. Jakarta.

3. Aldrian E., Djamil, Y.S. (2008) Spatiotemporal climatic change of rainfall in East Java Indonesia, Int. J. Climatol. Int. J. Climatol., 23. 435-448.

4. Bennekom, A.J., and Salomons, W. in River Inputs to the Ocean Systems (eds Martin, J.M., Burton, J.D., Eisma). 33-51 (UNEP, IOC, SCOR, United Nations, New York, 1981).

Tabel 3. Nilai Z hasil perhitungan metode Mann-Kendall yang menunjukkan kecenderungan naik (+) dan turun (-) dari debit bulanan di bagian hulu DAS

\begin{tabular}{|c|c|c|c|c|c|c|c|c|c|c|c|c|c|}
\hline No & Stasiun & an & Feb & ar & Apr & lei & Jun & Jul & Agt & ep & Okt & Nov & es \\
\hline 1 & ber & ,13 & 4 & . & 2,30 & 1,0 & 0,23 & -1 , & & 0,77 & 1 & 86 & , 80 \\
\hline 2 & 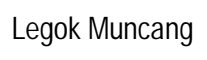 & $-1,30$ & $-1,19$ & -157 & $-1,92$ & ב- & 8 & $-0,86$ & & $-1,73$ & $-1,11$ & 97 & ,48 \\
\hline 3 & Cikapundung & $-0,94$ & -1 & 1, & $-1,78$ & $-1,54$ & $-1,62$ & -2 & $-2,68$ & $-2,00$ & $-1,31$ & 9 & 1,55 \\
\hline 4 & ojons & $-0,7$ & $-1,76$ & $-1,78$ & $-2,37$ & $\underline{-2,9}$ & $-2,04$ & $-2,06$ & -1, & $-1,96$ & -1, & $-2,10$ & 2,71 \\
\hline 5 & Cilisung & $-1,31$ & $\underline{-2,62}$ & 0,8 & & -0 & -0, & 000 & 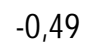 & & & & ,63 \\
\hline 6 & Banjarı & $\underline{-2,88}$ & $-1,27$ & $-1,06$ & ,05 & $-0,6$ & $-1,52$ & $-1,92$ & -0, & $-1,55$ & 0, & 0,00 & $-1,75$ \\
\hline 7 & das & 100 & $-4,48$ & $\underline{-2,75}$ & 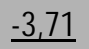 & -3 & $-4,34$ & $-3,30$ & - & 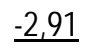 & -1 & $\underline{-2,77}$ & 2,98 \\
\hline 8 & Namba & $-<,<4$ & $-2, \mathrm{~d}$ & $-3,60$ & 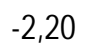 & -2 & $-0,68$ & $-0,9$ & -1, & $-2,17$ & -1, & $-1,18$ & $\underline{-2,87}$ \\
\hline 9 & iadang 74 & $-1,26$ & -2 & $-1,71$ & -1, & $-1,2$ & $-0,92$ & $-0,92$ & -2 & $-1,87$ & $-1,47$ & $-2,32$ & $-1,10$ \\
\hline IV & dang 91-03 &., 85 & 3,22 & 1,71 & $-<,<0$ & 0,00 & $-1,58$ & $-0,69$ & 0,07 & $-0,21$ & 0,34 & 0,75 & $-0,75$ \\
\hline
\end{tabular}

Keterangan: $1,645 \leq Z<1,96$ ditandai arsir; $1,96 \leq Z<2,576$ ditandai dengan cetak tebal; $2,576 \leq Z<$ 3,292 ditandai dengan cetak tebal garis bawah; $Z \geq 3,292$ ditandai dengan cetak tebal arsir 
5. Conley, D.J., Schelske, C.L., Stoermer, E.F. (1993) Modification of the Biogeochemical Cycle of Silica with Eutrophication. Marine Ecology Progress Series 101:179-192.

6. Hirsch R.M., Slack J.R. and Smith R.A. (1982), Techniques of Trend Analysis for Monthly Water Quality Data, Water Resources Research 18(1), 107-121

7. Humborg, C., Ittekkot, V., Cociasu, A., Bodongen, B.V. (1997) Effect of Danube River Dam on Black Sea Biogeochemistry and Ecosystem Structure. Nature. Vol. 386, 385-388.

8. Lettenmaier, D.P. (1988). Multivariate Nonparametric Test for Trend Water Quality. Water Resources Bulletin 24 (3), 505-512.

9. Libiseller C. and Grimvall A. (2002), Performance of Partial Mann-Kendall Test for Trend Detection in the Presence of Covariates, Environmetrics 13, 71-84

10. McCabe, G.J., Clark, M.P., Serreze, M.C. (2001) Trends in Northern Hemisphere Surface Cydlone Frequency and Intensity. J.Climate 14. 2763-2768.

11. Pawitan, H., Lass, I., (1996). Keseimbangan Air Hidrologi di Indonesia Menurut Kabupaten (Hydrology Water Balance of Indonesia). FMIPA IPB. Bogor

12. Pawitan, H., Jayawardena, A.W., Takeuchi, K., Lee, S. (2000). Catalogue of Rivers for Southeast Asia and the Pacific. Volume I-V. The Unesco-IHP Regional Stering. Committee for Southeast Asia and the Pacific. Japan.

13. Pawitan, H., (2002) Mengatisipasi Krisis Air di Indonesia Memasuki Abad 21. Peluang dan Tantangan Pengelolaan Sumberdaya Air di Indonesia. Editor: Sutopo Purwo Nugroho, Seno Adi, Bambang Setiadi. P3TPSLK BPPT-HSF. Jakarta.

14. Pawitan, H., (2004). Perubahan Penggunaan Lahan dan Pengaruhnya Terhadap Hidrologi Daerah Aliran Sungai (Land Use Change and Their Impact on Watershed Hydrology). Prosiding Multifungsi Pertanian. Balai Penelitian Tanah. Bogor.

15. Shaw, E.M., (1991). Hydrology in Practice (2 nd ed). Chapman and Hall.

16. Shiklomanov, A. (1997) Comprehensif Assessment of the Freshwater Resources of the World: Assessment of Water Resources and Water Availability in the World. World Meteorological Organization and Stockhlom Environment Institute. Stockhlom.

17. Soetamto (2009) Perubahan Pola Musim dan Curah Hujan di Indonesia. Makalah FGD Identifikasi Dampak Perubahan Iklim Global pada Sektor Sumberdaya Air. Jakarta.
18. Walsh, J.E., (2000) Global Atmospheric Circulation Patterns and Relationships to Arctic Ocean, E.L. Lewis et al., Eds. NATO Science Series 2: Environmental Security, Vol. 7. Kluwer Academic, 21-43.

19. Yue, S., Pilom, P. and Cavadias, G. (2002) Power of the Mann-Kendall and Spearman's rho tests for Detecting Monotonic Trends in Hydrological Series. J. Hydrol., 259, 254271.

\section{LAMPIRAN}

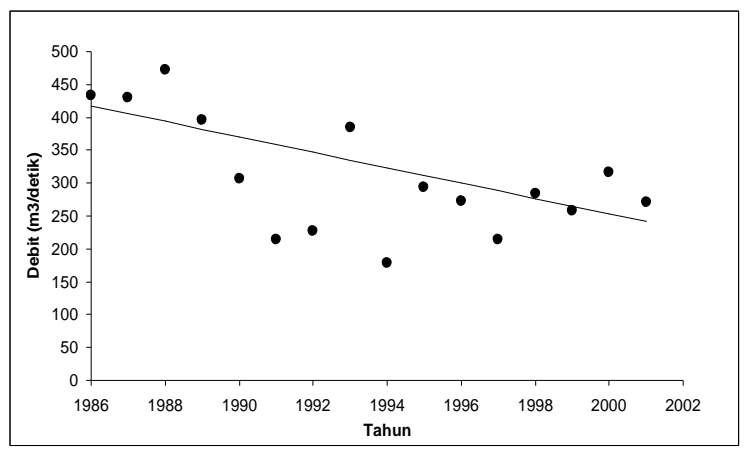

Gambar 2. Kecenderungan debit sungai di bagian hulu DAS di Stasiun Ciberang, Ciujung

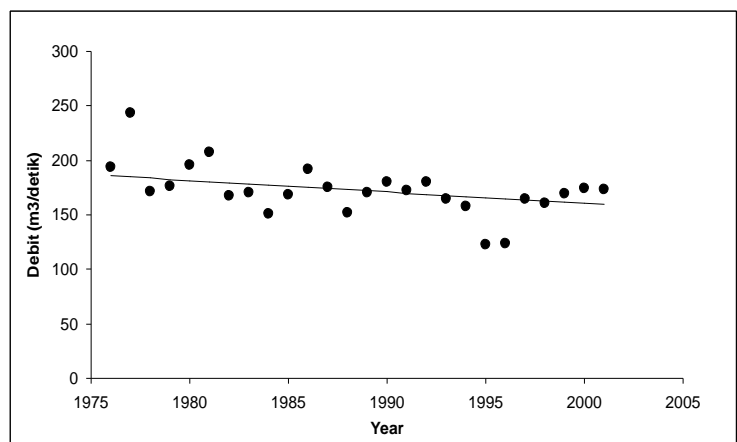

Gambar 3. Kecenderungan debit sungai di bagian hulu DAS di Stasiun Legok Muncang, Cisadane

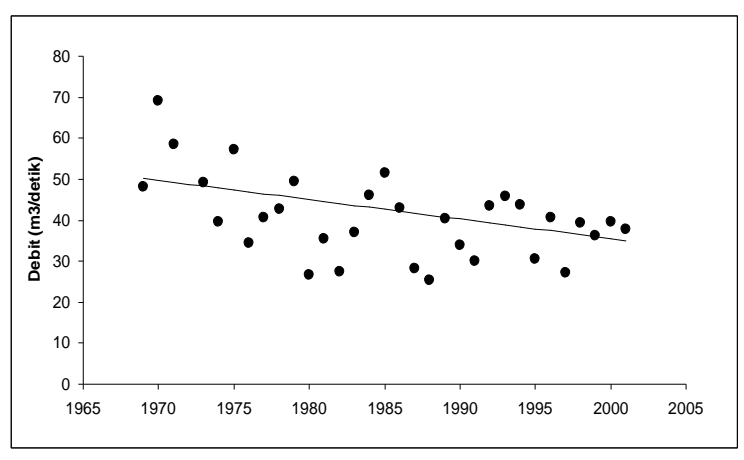

Gambar 4. Kecenderungan debit sungai di bagian hulu DAS di Stasiun Cikapundung, Citarum 


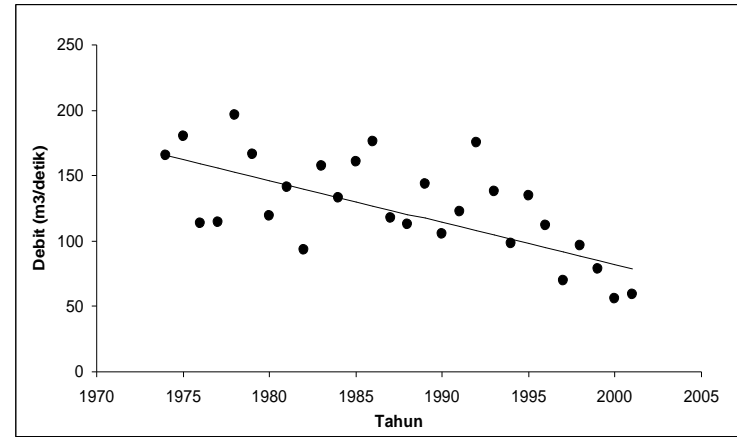

Gambar 5. Kecenderungan debit sungai di bagian hulu DAS di Stasiun Bojongloa, Cimanuk

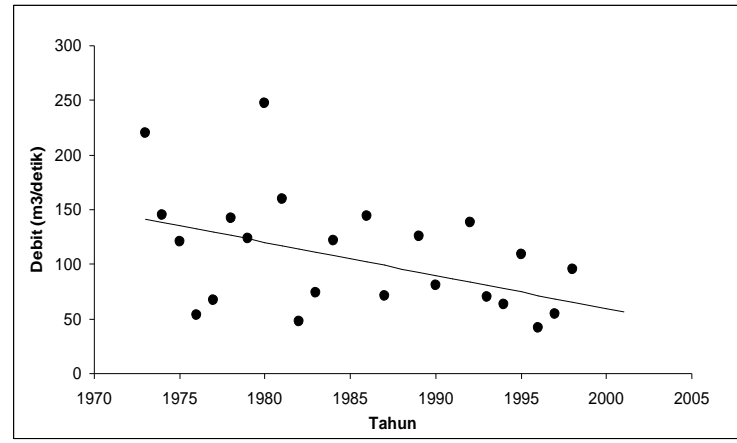

Gambar 6. Kecenderungan debit sungai di bagian hulu DAS di Stasiun Cilisung, Citanduy

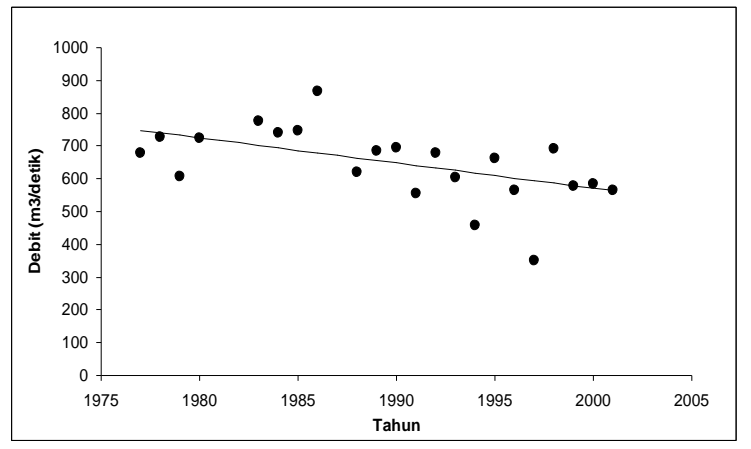

Gambar 7. Kecenderungan debit sungai di bagian hulu DAS di Stasiun Banjarnegara, Serayu

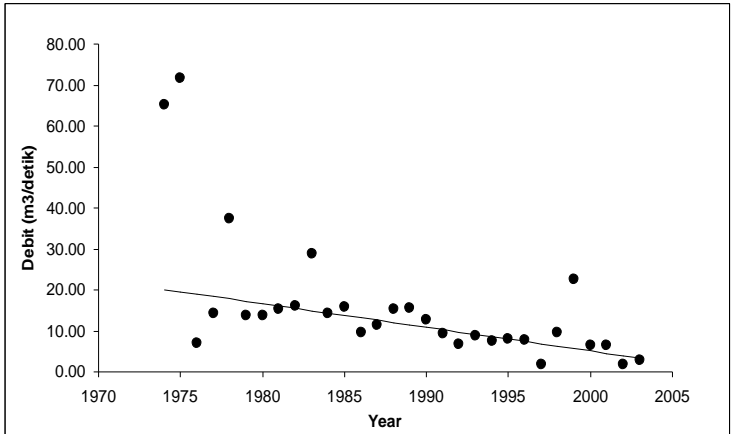

Gambar 8. Kecenderungan debit sungai di bagian hulu DAS di Stasiun Padas, Bengawan Solo

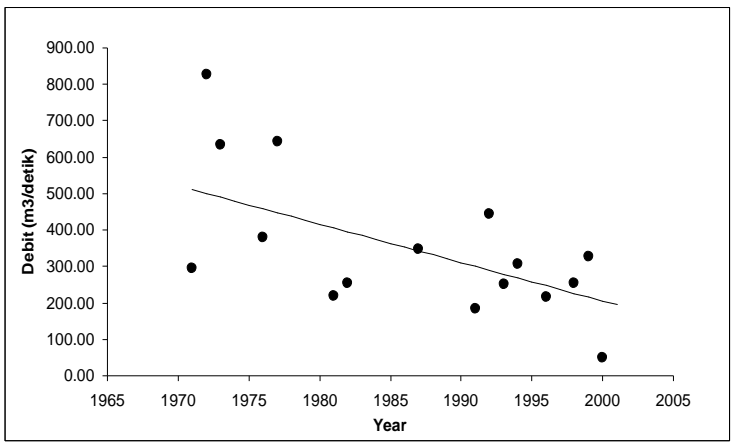

Gambar 9. Kecenderungan debit sungai di bagian hulu DAS di Stasiun Nambangan, Bengawan Solo

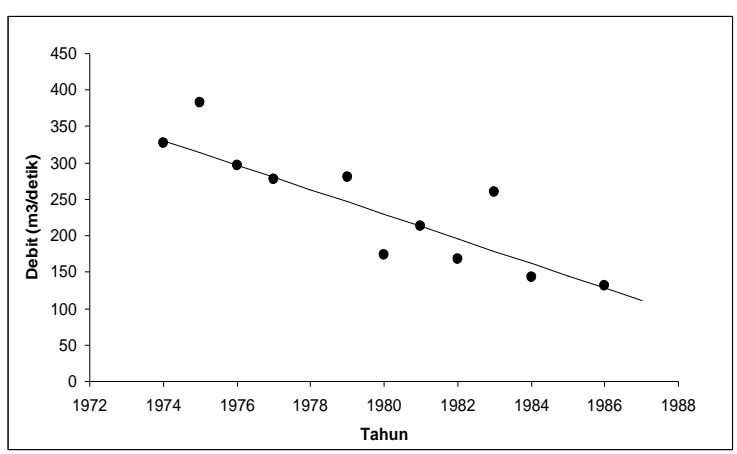

Gambar 10. Kecenderungan debit sungai di bagian hulu DAS di Stasiun Gadang, Brantas 